\title{
CIVILIZATIONAL SOCIOLOGY AND PERSPECTIVES ON THE ATLANTIC
}

\author{
Jeremy Smith
}

This paper calls for an opening of dialogue on the historical character of the Atlantic world between two fields. To date, historical sociologists researching the significance of intercivilizational encounters have not paid a great deal of attention to the case of the Americas. While historical and comparative sociology has assimilated the lessons of post-colonial critique, the starting histories of transatlantic colonialism have not had the impact on studies of civilizations carried out in this field that they should have. When it comes to the second field, Atlantic Studies, the paper argues that sociologists working in the first field have something to offer in their re-theorization of the character of long term inter-civilizational contacts. A fresh approach to the study of civilizations is sketched out here that reconstructs theoretical conclusions drawn in historical sociology in a way that will be of interest to specialists in Atlantic Studies. The first part of the paper examines the historical sociology of civilizations and sets out a new framework that revolves around a re-conception of radical difference and Otherness. In the second section, I explore how dimensions of the historical experience of transatlantic colonialism - such as mapping, place-naming and early ethnological curiosity constituted the Americas as a vital zone of the growing sense of civilizational superiority amongst Europeans between the 16th and 18th centuries. In this section, the article argues that civilizational sociology would profit from a systematic examination of this crucial historical zone. The conclusion puts out a call for further detailed inter-disciplinary research that combines the best insights of both the fields of Atlantic Studies and civilizational sociology.

KEYWORDS: civilizational sociology; colonialism; civilizational imaginary; Atlantic world

\section{Introduction: Civilizational Sociology Reviewed}

Within social theory and comparative social science, there is a rising interest in a type of scholarship that styles itself as 'civilizational sociology'. ${ }^{1}$ This relatively new genus of sociologists takes broad, multi-societal historical formations as its unit of analysis. Its existing and potential appeal to comparativists, inter-culturalists and area-studies scholars is its very object of research: the encounters between the major historical empires that have been best remembered and most documented by historians. It invites a more farreaching examination of flows of goods, ideas, people, armies and beliefs. The intensity

1 Two journals have sought to capture the conceptual sea change in comparative sociology about civilizational theory. See International Sociology 16, no. 3 (2001) and Thesis Eleven 62 (2000). Each issue is dedicated to the theme of civilizations and draws together a number of perspectives. 
and types of contact between historical societies come into focus, even where different societies regard each other with great hostility. Against Samuel Huntington, the best scholarship of civilizational sociology reveals that civilizations rarely 'clash' pure and simple, but are deeply embedded in a variety of external relationships that only sometimes involve conflict. ${ }^{2}$ In a broader sense, the relationships are historical, are ongoing, and compel internal change. Post-functionalist comparative perspectives, as practiced by S. N. Eisenstadt, Johann P. Arnason and Benjamin Nelson, for example, are based on a premise that human societies of the past were interactive and porous more than they were closed, defensive or isolated. Their work points to the conclusion that the level of inter-cultural contact from the High Middle Ages to the early modern era between the major civilizational centers of Western Europe, the Islamic empires, Eurasia, China, India and Japan is still underestimated. It is the major contention of this article that this field of research has a good deal to offer Atlantic Studies and that, in turn, it also has much to learn from a systematic study of the Atlantic zone, which it has thus far paid little attention to. To this point, there has not been a significant level of dialogue between the two fields. This article constitutes a plea for inter-disciplinary redress of this lacuna in both areas.

The starting point must be a clarification of terminology and some remarks on the politics of the terms used. 'Civilizational' is employed as an adjective to denote cultural features of multi-societal forms. In the current work, it is applied to Western European, Mesoamerican and Amerindian cases. The idea of 'civilization', and indeed the very word itself, needs clarification and its use involves distinctive risks. Civilization is referred to in two ways. First, it alludes to historical formations, such as the ones mentioned in this article. In this usage, it is plural and does not automatically connote a sense of cultural or race-based pre-eminence. Second, it is taken as a historical artifact of European conceptual thinking that coalesced in the 18th and 19th centuries. This is 'civilization' in the singular and it evokes cultural primacy. As a historical concept, the term has been subject to comprehensive post-colonial critique. The risk in re-utilizing it must be stated if the pitfalls so amply highlighted in post-colonial criticism are to be avoided. It involves the danger of uncritically and unreflectively taking on the language of civilization, which brings with it a legacy of self-belief in Western superiority. This is a heritage internal to the very notion of civilization and is evident from an etymological study of the word. ${ }^{3}$ The salient point to emphasize is that the recognition of 'civilization' as a notion inherited from the era of European imperial domination must be the premise of the kind of revision of thinking suggested in the scholarship of civilizational sociology. In other words, dealing with the historical and conceptual baggage of the word is part of rescuing the idea from its own heritage for a wider purpose in comparative and historical study. Studying civilizations sociologically today therefore involves problematizing the conceptual background of the human sciences associated with it.

The overall argument here thus aims to establish a framework for exploring the general interactivity of civilizations and of how circum-Atlantic encounters sharpened European self-awareness. I start by briefly canvassing existing sociological approaches to the study of other civilizations to set out the contours of the field. The study then moves to launch a distinct theoretical basis for examining civilizational consciousness in the Atlantic zone. The last section of the paper outlines how this theoretical framework could

${ }^{2}$ His program is set out, mainly, in Samuel Huntington, The Clash of Civilizations.

${ }^{3}$ See the editors' introductory essay in Rundell and Mennell, Classical Readings. 
be applied to the historical experience of transatlantic colonialism. There is a focus on mapping, place naming, and the early tradition of ethnological thinking.

Civilizational sociology reveals that past perceptions of civilizations in the human sciences can be split into two classes: those who define it in the singular as the attainment of a standard of economic, political, and moral development and those who can perceive and conceptualize many different forms of cultural, religious, and political order. ${ }^{4}$ Three further analytical clusters of civilizations can be identified. One approach organizes on the plane of world histories and casts the major religious and philosophical breakthroughs of Antiquity as the great cultural watersheds of many civilizations. The vital development that is sought is the point at which secular and sacred authority became separate entities. This is labeled as the 'Axial transformation' and it refers to changing metaphysical conceptions of the world order that occurred between $500 \mathrm{BC}$ and the first century of the Christian era. The premises established during these formative periods of ontological re-conceptualization of the world became entrenched in the dominant ideologies of leading elites. Notwithstanding their revision over time, remain the cultural premises of identifiable civilizations. A second approach is exemplified by sociological studies of the so-called civilizing process that follow Norbert Elias' pioneering work. They often treat civilization in the singular as a long-term historical process, even when a number of civilizations are under consideration. A third class of sociology defines and studies civilizations as cultural formations that unify otherwise diverse groups of societies around sacred and religious premises. From this class, Emile Durkheim, Marcel Mauss and Johann Arnason are discussed.

Some detail from each class can serve to establish where the sociology of civilizations stands. Shmuel Eisenstadt and Benjamin Nelson represent the strongest advocates of the first understanding of civilization. In Eisenstadt's view, civilizations are forged out of what he characterizes as Axial advances, or, in other words, the transformation of religious and philosophical principles that makes possible self-conscious. reflection on the nature of the social order..$^{5}$ It is around the tension between transcendental visions and worldly experience that civilizational identity crystallized in Antiquity. The historic period in which this transformation came through for Europe is thought to be the flowering of Greek schools in the fifth to the third centuries BC, where the authority and legitimacy of inherited tradition was challenged. It rendered all spheres of social life questionable including law, politics, and philosophy. This achievement of Hellenic Antiquity, rather than anything today, might be recognized as pan-European. Given the diffusion of the legacy of this rich culture throughout the Islamic world, the Axial breakthrough might be better seen as a development at the crossroads of different societies. It was a watershed in world-historical terms and its later revival was vital to the European trajectory.

Elsewhere, Eisenstadt posits the leap into the modern world and the leading role of the West in it. Europe's decisive advantage lay in the institutional constellation of its social and political structures and the competition of elites that it contained. ${ }^{6}$ The modern world

\footnotetext{
4 Johann P. Arnason, "Social Theory and the Concept of Civilisation", 87-8.

${ }^{5}$ Eisenstadt's original outline of the notion of axial transformation remains the most far-reaching. See Esisenstadt, The Origins and Diversity of Axial Age Civilizations.

${ }^{6}$ Eisenstadt, European Civilization in a Comparative Perspective.
} 
originated in this Europe and it constituted a civilization in its own right. ${ }^{7}$ The "civilization of modernity" was, or it is, distinguished by its ideological foresight. Its rationalism in science, law, and philosophy gave its culture critical depth and echoed the problematization of the mundane order that had been established in Ancient Greece. Industrial and capitalist economic development made Europe a civilizational powerhouse. Its autonomous figuration of power provided a worldwide model of state formation that privileged multi-polar, smaller state units. For Eisenstadt, this compendium of achievements exemplified the modern world, a radical realignment of cultural orientation that reaffirmed the ideals of Greece, but that also went a good deal further. Modern civilization then spread to the rest of the world in a confrontation with other civilizational forms during the period under discussion here.

Benjamin Nelson also sees Axial breakthroughs as the pivotal moment in the life of a civilization. ${ }^{8}$ In his terms, civilization is a "frame of reference" forged at the intersections of cultures and from productive internal conflicts. This frame can incorporate many societies and it is marked off from other sociological categories (like the notion of "society" itself) by its application of broad "paradigmatic cultural patterns", a definition consistent with other thinkers considered here. As with Eisenstadt, Nelson follows Karl Jaspers' parent notion of Axial transformation of the "structures of consciousness". The most prominent type of structure is Europe's rational consciousness and, in Benjamin Nelson's view, the critical period is the twelfth and thirteenth centuries. ${ }^{9}$ It was during this period that "the new logic and the new dialectic" began to alter the relationship between faith and knowledge. The thirteenth century was, therefore, a renaissance of critical inquiry into the world, one in which rationalistic philosophy enjoyed a good reputation in Christian Europe. This is the most decisive and comprehensive development on the road to rationalist consciousness. It is a breakthrough either ignored or understated elsewhere and it serves to highlight the neglect of monasticism as an early incubator of rationalism. In this way, Benjamin dates Europe's decisive cultural shift earlier. The difficult and uneven emergence of science has a longer history that can be rooted in monastic and clerical developments. Modern Europe had its origins in the rationalization of thought for Benjamin and this produces an explanation of Axial developments quite different from Eisenstadt's. Consequently, it produces another chronology also.

No discussion of sociological conceptions of civilization is adequate without a reference to Norbert Elias. ${ }^{10}$ For Elias, seismic shifts in culture are only properly understood in relation to economic developments, urbanization, the modification of behavior and, above all, the emergence of centralized states in Europe from the sixteenth century onwards. His notion of the civilizing process combined historical investigation of codes of conduct and self-restraint with explanations of the figuration of power, the rise of the money economy and urbanization. The taming of warrior behavior and the refinement of manners were evidence of a civilizing process whose impulses reach back beyond the Renaissance. With the rise of the absolutist court society, a civilized ethos of life became intimately connected with a transformation of the figuration of power. Centralization of

\footnotetext{
${ }^{7}$ Eisenstadt, Patterns of Modernity. See especially the opening introduction.

${ }^{8}$ Nelson's views are well collated and explored in Huff, On the Roads to Modernity.

${ }^{9}$ Huff, On the Roads to Modernity, 'Preface'.

${ }^{10}$ See Elias' landmark sociology of state formation, State Formation and Civilization.
} 
the instruments of rule and the refinement of courtly conduct went hand-in-hand as codetermining processes and they were impelled by economic and urban development.

Elias understands civilization as the self-pacification of warrior conduct. "Civilized" denotes a singular normative standard of manners, language, intercourse, and custom and is expressed in the 16th century notion of civilite, the means by which courtiers distinguished themselves from their rough forebears and barbaric outsiders. Debates within the bourgeois intelligentsia in France and Germany captured the logics in play and helped to shape new standards. In this sense, Elias' theory of the civilizing process revolves around the manifestations of a normatively distinct mode of behavior and self-constrained conduct along with their corollary, the consolidation of territorial power. As he sees it, this was a matter of a self-consciousness of civilized standards on the part of early modern court elites.

Courtly self-constraint and allied forms of rationality are evident in other civilizational centers, but this is scarcely acknowledged. In one crucial respect, Elias' sociology neglects the impact of societies to Europe's east. Civilizing processes in other societies may be greatly developed, but the manner in which regular inter-civilizational contact induces norms of social constraint is conspicuously absent from his sociology of manners. In this regard, Elias takes civilization in the singular. The European acculturation of standards of civilized conduct that resulted from the encounter with America is not admitted into his historical sociology and cannot be without the expansion of the scope of analysis to encompass inter-civilizational encounters. Encounters in the American hemisphere must have had consequences in ways that are difficult to untangle in Elias' framework of endogenous movements. Instead, colonialism appears as a one-way process in which Europeans' normative standards are imperfectly disseminated, while the influence of images and interpretations of America on the temperament of behavior attract little comment. Elias' chief insight into civilization as self-consciousness unfortunately fades at the critical stage. His work is, therefore, a point of departure in this essay's re-conception of civilization.

The analyses of Elias, Nelson, and Eisenstadt are premised on the assumption that states and empires have a civilizational aspect to them, but do not represent an entire civilizational mass. However, for the conflicts and encounters associated with colonialism (especially in the forms that it took in the Atlantic world) to be seen as, in part, civilizational, the category of civilization itself needs to be further refined. It does not solely denote an Axial breakthrough (or series of them) or a process of civilizing the norms of conduct and the consolidation of power. For the purposes of the argument in this article, it is better understood as a sort of consciousness actualized in a variety of social practices that distinguishes broad multi-societal formations. The third class of civilizational sociologists identified above has made valuable contributions towards this kind of comparative sociological understanding. Emile Durkheim and Marcel Mauss can be put together as they experienced a confluence of ideas that produced an original synthesis, which echoes in contemporary civilizations sociology. ${ }^{11}$ Durkheim's early sociology stressed the functional division of labor in self-contained national societies. His later turn to anthropology was a move to a plane of cultural comparison. The border-bounded society was problematized as a unit of analysis, as was a notion of civilization that

11 Durkheim and Mauss, "In Between Sociology and Anthropology". See, Rundell and Mennell, Classical Readings. 
privileged the unity of societies in symbolic representations. ${ }^{12}$ This met Mauss' own anthropological insights that concentrated on the cultural fabric that tied societies in a civilizational zone.

Durkheim and Mauss, therefore, generated two notions of civilization. First, civilization is a cultural form subject to "rationalization," that is to national appropriation or modification by states. However, it cannot be completely confined to any particular state. So stateless societies can be attributed a cultural unity-of-sorts, a move supported to some degree by ethnographies of their day. This implies that civilization can only be understood in the plural, as delineable cultural unities.

Second, the attention paid to the symbolic dimension in their neglected writings paved the way for a notion of civilization that did not bind itself to the project of nationalism of any one state and indeed is open to further non-Eurocentric elaboration. To Durkheim, this was a conscience collective, or a fabric of taboos, representations, and symbols that sacralized meaning across pre-industrial societies. Generally, it implied that the proper domain for the study of civilization is not manners or the emblems of progress so much as the symbolic realm in which social intercourse is made meaningful.

Max Weber's contribution to sociology remains relevant today, but the significance is complicated and sometimes marred. For Arnason, Weber produces results that isolate cultural zones for analysis, even though there is little of a pre-existing conceptual framework to maximize the potential conclusions. ${ }^{13}$ Weber identifies "cultural areas" and "centers," but does not elucidate original theoretical principles for the distinctions that he makes. The European center is analyzed extensively, especially in The Protestant Ethic. However, China, India, Japan, and other centers of the Oriental zone are not treated conclusively and so comparative insights are only preliminary. Culture is read through the sociologies of religion and rationality, which constrain the breadth of conclusions that could be drawn. These are the threads of a framework that Arnason more properly calls post-Weberianism. The prelude to this is a re-conceptualization of the inter-linkage of "culture" and "power" in which neither is seen as inert and both are mutually modifying. Instead of "power" and "culture" appearing as juxtaposed "things," both can be seen as varying across history and across different civilizational bases. If this is so, then there seems to be little reason to view civilizations as sealed, and not dynamic and self-transforming, formations that were more-or-less remote from each other until the modern age. I argue elsewhere that this is a basis for some interesting comparisons with Eisenstadt's work. ${ }^{14}$ There is a conceptual reworking of Weberian schools of thought between them that clears the ground for a comparative sociology that can stress inter-civilizational contact and exchange over the longue durée instead of isolation.

The third class of theorists offers the most salient historical understanding of intercivilizational relations. The potent image to draw from this current is one of civilizations as geo-cultural constellations of discrete societies that embody unity-in-tension. This means that civilizations have been harmonized by an overarching cultural imagery, but have also been demographically, ethnically, and economically diverse. Many historians researching

12 Rundell and Mennell, Classical Readings, see especially $20-1$.

13 Arnason, Social Theory, 58-60.

${ }^{14}$ Little comparison of Eisenstadt and Arnason is available in the literature and yet their own exchanges, affinities, and debated differences beg further analysis. See Smith, "Theories of State Formation", 225-51. 
in the vein of civilizations analysis have demonstrated that such clusters often encompass a rich diversity of peoples, migratory movements, beliefs, and styles. Historical civilizations are therefore better seen as open to internal alterations prompted by contact with other societies and geo-cultures. What brings them together, according to the view that I am expounding here, is a civilizational imaginary that enables inter-cultural connections. Ethnic, economic, political, or even linguistic homogeneity is not a requisite pre-condition for coherent civilizational perception to exist and often heterogeneity has prevailed.

\section{The Civilizational Imaginary}

My main theoretical proposition around the civilizational imaginary is laid out in two contentions. First, civilizational consciousness is symbolic and signifies social institutions, customs, and practices that situate the ontological boundaries of difference and identity. Second, following Cornelius Castoriadis, civilizational consciousness rests on an inherited and emergent imaginary. Castoriadis and others articulate a version of the imaginary that is distinguished from others' (including Jacques Lacan's) by its focus on abstract social significations; that is the image making that takes place as a necessity in all societies:

(E)very society defines and develops an image of the natural world, of the universe in which it lives, attempting in every instance to make of it a signifying whole, in which a place has to be made not only for the natural objects and beings important for the life of the collectivity, but also for the collectivity itself, establishing, finally, a certain 'world order'. ${ }^{15}$

This conception of the imaginary stresses the human source of these images, symbols, language, myths, rules, conflicts, and structures. Without these forms, human existence would be chaotic and without system. ${ }^{16}$ They also incorporate components of civilizational identity, as they establish the symbolic borders by which social actors constitute difference meaningfully. Forms of knowledge, manners, sacred belief, and behaviors are rendered recognizable, or are alternatively obscured, in inter-civilizational encounters by the degree of commensurability of imaginary significations. In other words, the capacity for inter-civilizational exchange is guided by the extent of mutual comprehension of symbolic forms. The civilizational imaginary also demarcates the parameters in which an awareness of comparative cultural coherence can emerge.

To this first understanding of the civilizational imaginary, I must add the second contention. The imaginary is comprised of traditions and the scope for internal transformation. Two elements of Castoriadis' theory of the social imaginary give some purchase on the process of change that occurs in the crucible of civilizational contacts and engagement. These two elements are, in Castoriadis' words, the "instituted" and "instituting" imaginary:

On the one hand, it is given structures, "materialized" institutions and works, whether these be material or not; and, on the other hand, that which structures, institutes, materializes. In short, it is the union and the tension of instituting society and of instituted society, of history made and of history in the making. ${ }^{17}$

${ }^{15}$ Castoriadis, The Imaginary Institution, 149.

16 Castoriadis, "Radical Imagination", 136-54.

17 Castoriadis, The Imaginary Institution, 108. 
Arnason retheorizes this as "creative transformation."18 His rendition amplifies Castoriadis' original notion through the presumption that all social formations primarily, though variously, rest on inherited structures and visions. Where Castoriadis places the accent on the novelty of world-historical cultural breakthroughs, for Arnason the weight of tradition falls more heavily on the makers of history. The implication of this view is that the inventiveness of cultural breakthrough is exaggerated by Castoriadis and that ideas always depend upon given traditions in acts of radical reinterpretation. However, the weight of inherited traditions is not conceived of as an unshakeable burden. Historical agents are engaged in processes of creative change. Arnason's reconsideration minimizes some of Castoriadis' formulations, while accentuating others. This is a helpful reformulation in which social and cultural change is conceptualized in terms of existing structures and traditions derived from the past, whilst accounting for creative agency mobilized in the present.

Arnason makes an important assumption relevant to this discussion of the civilizational imaginary. In the formation, growth and renovation of societies, creation, and reproduction are always inter-related. The central image becomes one of collective arrangement and reorganization based on an inherited order and a creative horizon. Implicit in this conclusion is the assumption that societies are anything but closed entities. The societies that interact within a civilizational cluster or with other civilizational forms are dynamic combinations of traditions and change.

This insight at the heart of Arnason's reworking of Castoriadis enables a more flexible and open-ended historical sociology of particular cases of inter-civilizational exchange and collision. The instituted and instituting imaginary, reformulated by Arnason as creative transformation, can be recast as existing civilizational traditions combined dynamically with emergent signs that materialize during the course of interaction with other civilizational forms. The civilizational imaginary can now be considered an amalgam of inherited and instituting signs that animate social meaning in a way that guides responses to encounters with wholly different societies, social formations, and peoples. Understood in this way, civilizational consciousness involves ideas derived from an imaginary that is mainly an assembly of signs that lends general meaning to events. It becomes a set of symbolic standards by which others could be judged in terms of societal, economic, and political development. In turn, this sets the parameters of engagement.

In Western Europe's early modern period, the animation of meaning in Atlantic encounters stimulated a sharpening of civilizational awareness, or a consciousness of cultural specificity. This consciousness can be gauged in the growing comprehension of cultural juxtaposition of the societies of Western Europe and those of the Amerindian, Mesoamerican, and West African worlds. The second part of this essay involves a substantive application of this outline of a theory of the civilizational imaginary. Between the 16th and 18th centuries, the confrontation with the unfamiliar American world interrupted and transformed European views. A fluid consciousness was expanded in the momentous ferment of interaction with the Americas. The early centuries of transatlantic engagements generated a self-ordering image of civilization for Westerners that drew on both established traditions and newly forming impressions of an unfolding Atlantic world.

18 Arnason, "Culture and Imaginary Significations," 38-44. 


\section{The Atlantic as a Civilizational Zone}

Civilizational sociology has not as yet come up with an in-depth study of the Atlantic theatre. The argument here seeks to address this hiatus by developing a notion of civilizational imaginary that might be of interest to both Atlantic scholars and historical sociologists. To put this in more specific terms, Europeans in their encounters in the Americas invoked imaginary traditions of Rome and of conquest (an instituted imaginary) and materializing signs of civilization (an instituting imaginary). The remainder of this essay treats each civilizational imaginary and the consciousness derived from it in turn.

\section{Traditions of Expansion: Rome and Conquest}

The conquest of America had historical precedents that served as a paradigm for its execution. Above all, an enduring image of Rome served as a great tradition of Empire. Its legacy included the notion of Universal Monarchy. Its association with the Kingdom of Christendom receded. What Rome signified varied from one state to another. ${ }^{19}$ The Portuguese believed themselves the heirs of Rome, due to the size of their empire and the excellence of their sciences. The French incorporated Roman art into sixteenth century ceremony and legal codes into juristic theory. In turn, Roman legal principles supported the claims of lawyers that the French monarch was imperator in regno suo. The English monarchy exercised a different and more wide-ranging relationship to the legacy of imperium left by Rome. For example, English possession in North America was legitimated by reference to the literary classics. Spain fervently claimed to inherit the entire legacy of Rome, viz. the custodianship of Christendom. This claim and the rigor of its pursuit, in turn, led Spain to a firmer embrace of the project of a universal monarchy. All built empires in the image of Rome as that image was variously projected. All laid claim to the universality of their sovereignty over land and sea based on Roman ancestry.

This was a background for the four main imperial states that colonized the Americas. In addition to the potent interpretations of Greco-Roman traditions, there are further sources of inspiration. Three traditions of conquest are under consideration here: medieval crusading colonization, the reconquista and England's incursions into Ireland. Each is detailed below.

The expansion of Christendom brought Europe's warrior cavalries together in common ventures. ${ }^{20}$ This was more than just a forward movement. Latin Europe looked to the Baltic, the East Mediterranean, Jerusalem, and the south of the Iberian Peninsula for territorial and ecclesiastical expansion. Territory formally under control was consolidated with the decree of new lordships, towns and the organization of further bishoprics. There is ample evidence of an "expansionary mentality" (Bartlett, 90-6) that emerged from the system of colonization in new laws drafted and the literature and poetry that emerged.

Latin Europe therefore had methods of internal colonialism that could be used in the Americas. It combined the seizure of land with the creation of ecclesiastical missions and chartered townships and administration. One symbolic element was retained in the advance into the Atlantic, even though this quickly became anachronistic after the 16th

19 See, in particular, Armitage, The Ideological Origins, 29-36, Patricia Seed, "Conclusion: The Habits of History" in Seed, Ceremonies of Possession and Pagden, Lords of All the World, ch. 1 and 2.

${ }^{20}$ Bartlett, The Making of Europe, 250-68. 
century. Spain's sovereign claim to "universal monarchy" was blessed by the Vatican. Papal sanction lent legitimacy to the seizure of the newly found islands in the Caribbean basin. It was a valuable gesture for the Spanish as it demarcated new international lines of control, even though they did not prove durable. It also represented a resolution of the tension between the legitimation of rule and existing jurisdiction in the Americas that was preferred by the high apparatus of the Spanish state, as opposed to Cortes' image of a dominion of New Spain. ${ }^{21}$ It provided continuity with the established and respected approach to colonization. This was vital as the new situation brought about by Columbus' voyage called for oceanic, rather than strictly territorial, expansion. ${ }^{22}$ The wider late medieval growth of Christendom provided a necessary backdrop to the conquista.

The Spanish edifice has been described as an empire that founded and continued its own specific tradition of conquest. ${ }^{23}$ Spanish colonization was an inter-continental re-run of the late 15th century conquista that unified the peninsula under the Catholic monarchs. The original invasion of the Islamic south of the peninsular was not a sudden movement, but occurred between the 11 th and 13th centuries. A method of conquest took shape during the long campaigns in the Iberian south. Successful expulsion or conversion of Jews and Muslims established a religious despoblado. Hispanic Christians then colonized the southern frontier. Many Islamic forms and rituals of warfare and conquest were appropriated by the conquerors and combined with Castilian traits. The result was a hybrid mode of conquest that had no immediate equivalent in Christian traditions of warfare. ${ }^{24}$ It was deployed in the Americas involving features that were Islamic in origin. At its heart was a most ritualized and elaborate protocol of conquest, the requerimiento. It was a "summons" to accept submission to a superior religion. Like the Arabic jihad, it did not require belief, only obedience. Thus, its style of proselytism affirmed a debt to Islam. Exposure to the Moors' conduct of war over time led to direct assimilation of its key elements into what became a Hispanic tradition.

The zealotry that had led to the reconquista in Spain was the triumph of Isabella's pre-union reign. Spain purged of heresy bred a martial mood. It established the monarchy as a leading power within and outside of Spain. While the four states all shared the impulse that led beyond the bounds of the old world, the Spanish conquest was distinct in its reach and vigor. Its uninhibited drive spread the sphere of Spanish possession from the Antilles on to the continent, to the south and deeper into the hinterland. The long historical experience of conquest imbued the conquerors with a specific outlook on wealth, land, and subjugated peoples. The singular tenacity of the Conquest did distinguish it in the sixteenth century from tentative English and French advances. The enthusiasm for conquest stands out, notwithstanding important clerical reactions against its excesses.

The third paradigm of conquest is English colonization of Ireland. This is controversial and debate continues amongst historians. ${ }^{25}$ Questions remain about whether Ireland really was a colony and, if so, whether there was continuity between

\footnotetext{
${ }^{21}$ Frankl, "Imperio Particular", 139-62.

22 Mancke, "Early Modern Expansion", 225-37.

23 Lang, Conquest and Commerce, chapter one and McAlister, Spain and Portugal.

24 See Patricia Seed, "The Requirement: A Protocol for Conquest" in Ceremonies of Possession.

${ }^{25}$ Canny, The Elizabethan Conquest; Ellis, Ireland in the Age of the Tudors; Morgan, "Mid-Atlantic Blues", 50-5.
} 
the colonization in Ireland and northeast America. The first question is beyond this paper, as is most of the debate. If judgment of Ireland as a kingdom or a colony is not conclusive, then a question mark also hangs over parallels drawn with early Anglo-American colonies and this raises doubts about whether Irish plantation was a colonizing tradition.

David Quinn and others have argued the strong version of the case that there was continuity. ${ }^{26}$ On their evidence, the parallel is a direct association. Some of English America's most important adventurers were also Irelands. Their experiences may not have traveled with them as enduring models, but there can be little doubt that their past exploits influenced their direction in settling America. A less direct relationship is suggested elsewhere. ${ }^{27}$ The Atlantic zone involved England in different colonial relationships each of which shaped an imperial mindset in distinct but comparable ways. Ireland was a "near periphery," while America constituted an "outer periphery." The Atlantic zone provided examples of diverse efforts to transform strange environments and those that inhabited them. Near and outer peripheries were zones of learning for English colonizers whose own doctrines were tested and altered as a result. Moreover, Ireland became a conduit in the British Atlantic. From the late 17th century, there was a sharp increase in the rate of transoceanic migration. At the same time, Irish ports began to service growing demand in British trade. Ireland's strategic location in the commerce with the West Indies, Virginia and the Amazonian coast, in combination with the greater flow of people into America, induced an Atlantic orientation.

There are other criticisms that bear on the question of models of colonizing briefly summarized here. The absence of intention to colonize Ireland raises questions about the idea of a "model" of colonialism implicit in the Quinn-Canny approach. While plantation settlements were experimented with in Ulster and Munster, they were not finished forms in any sense and were not transferable to an uncharted environment. Moreover, they encountered a very different reaction. The military strategy of Gaelic warlords in response to English encroachments transformed the Irish situation in fundamental respects; so much so, that comparison with the American colonies becomes untenable. Attitudes to the rebellious Irish may have informed subsequent dispositions to America's indigenes. However, both had more potent precedents to draw upon in the Romanesque juxtaposition of barbarianism, the ordered organization of urban life, and in AngloNorman traditions of conquest.

Evaluating these criticisms leads to one conclusion: the relationship to Ireland constituted a minor and fresh tradition in the English expansion into the Atlantic. Balanced comparison of the two theatres of colonial enterprise brings out the distinctions more than urging the similarities. Ireland resembled a realm of a composite monarchy far more closely than English America could. ${ }^{28}$ England's promotional materials cast an optimistic view over the opportunities there, while views of Ireland were shadowed by anxieties about civility's movable frontiers. Its proximity set it apart from America, even though it was also part of the greater English Atlantic. In addition, planting in English America was carried out in a land in which there were no precedents. Coexisting plantations in Ireland

${ }^{26}$ Canny, Kingdom and Colony; Quinn, "Ireland and Sixteenth Century European Expansion" and Ireland and America.

${ }^{27}$ See Jane Ohlmeyer's alternative perspective in "Seventeenth Century Ireland", 446-62.

${ }^{28}$ See Bottigheimer, "Ireland in the Westward Enterprise," 55-7, 60-1. 
were points of comparison, but North America was, at the time, a barely reconnoitered proposition, while the Irish frontier was more familiar.

Such points about the English experience in northern America are relevant also for the Spanish, Portuguese, and French cases. European colonization of the Americas involved the conquest of land, peoples, and radically different and unfamiliar social formations. Instead of simply engaging and trading with contrasting societies, different economic networks and familiar civilizational powers, European states inaugurated largescale settler-colonialism as a form of empire building and in doing so they invoked their interpretations of ancient and conquering traditions. These buttressed a crystallizing civilizational identity that could define itself against the opposite of America. This encounter with American Others was not confined to meeting new peoples. It encompassed a number of areas of cultural experience that were part of a transforming horizon of an instituting civilizational imaginary.

\section{Signs of Civilization}

Europe's invasion and conquest of the Americas did not just involve the mobilization of its existing traditions. The growth of the Euro-Atlantic empires stimulated a conception of civilizational specificity. Europeans ascribed norms of civility to their own advancement in order to establish a symbolic distance from the civilizational orders that they encountered. The breadth of European possession circumscribed the contours of civilizational thinking for supporters of colonial purpose, such as Sepulveda, Hakluyt, Bodin, and Acosta, and its mildest and most trenchant critics, from Las Casas to Montaigne and Charles Davenant. Civilizational consciousness had not crystallized in the sixteenth century in the way that it would in pre-revolutionary France or Britain after the Seven Years War. Yet there was a family of Latin and French terms associated with refinement and conduct regulated by manners. ${ }^{29}$ In the context of the debates over the Americas and the validity of ancient texts, a forming conception of civilization was endowed with the values of progress and exceptionality. The conceptual signage that buttressed European grasp of Asian, African, and American societies was materializing in this long period. It was only robust enough at this time to impart to Spanish, English, and French subjects an ambiguous language through which Europeans could either interpret themselves as the civilized or could refer to standards of civility in criticism of empire building.

This conceptual signage was the emergent or instituting imaginary. It provided the horizon for an interpretive paradigm of Europe's relationships with Amerindian societies. The expansion of Europe's imperial states was marked by a tension between their particularities and the general confrontation between European and Amerindian civilizations. Europe's civilizational imaginary contained universalizing patterns and ideals. ${ }^{30}$ Civilizational consciousness was forged in a dynamic of homogenization and countervailing heterogeneity. The actualization of this civilizational difference-or, more properly, consciousness of difference - is evident in four historical practices of Atlantic colonialism: cartography, place naming, historiography and the elaboration of the image of the noble savage. How each of these constituted signs of civilization is elaborated in more detail below.

29 Rundell and Mennell, Classical Readings, 6-7.

30 Arnason, "Social Theory and the Concept of Civilisation", 88-91. 
The world was re-mapped within European consciousness as a place foreign to Europe, but under the auspices of its major powers. Mapping cultivated this pretension. ${ }^{31}$ The development of cartography was precarious and unstable. Colonialism provided the impulse towards common standards of cartography within imperial states. The commensurability of spatial representations that imperial states strove for was one impetus to uniformity in cartography. Standard representations of the semiotics of space within Spain's Casa de Contratacion and Portugal's Padron Real animated European conceptions of the world as a series of imperial domains. The expansion of printing enabled a wider distribution of maps and intensified the competition for more advanced versions. The minimal Portolan charts ceded ground by the end of the 16th century to more elaborate and expansive Dutch maps. ${ }^{32}$ They captured the globe in a European conception that crossed Dutch, English, French, and Spanish experience. Imperial officials, merchants, and explorers constructed and read maps not only for practical purposes, but also to comprehend the extent of their national reach. Attempts to map the whole world indicate a desire to grasp the totality of humanity and bring it under the signs of civilization.

Unknown lands and continents were accepted widely by the third quarter of the sixteenth century. Maps flourished, carrying more detail of places colonized by European powers reassuring imperial elites of their control. They connoted a great mobility. Mapping and the signs made on maps in a way made the places themselves transportable. ${ }^{33}$ Those places could be unfixed and "read" in a form that was legible. This suited the Baroque culture of Counter-Reformation Europe as maps were designed to impress the visual senses and could act as the accessories of imperial identity. Cartography was an especial mode of representation that boasted the achievements of European state formation and that deepened civilizational identity. Concurrent processes of exploration and the cartographic charting of the non-European world were the initiation of imperial imagery of the globe and Europe's possessions in it.

Place naming involved a more literal institution of signs. It has been argued that the textuality of European culture was part of the colonizing process. ${ }^{34}$ If this is the case and if it can be seen as part of a cultural movement onto the American continent then New Spain was a front line. The Aztec world was "textually captured" over time. Initially, the romanization of Nahuatl ensured the displacement and slow demise of pictography. ${ }^{35}$ Mexican idiom utilized combinations of expressive forms for a period. Ultimately, the wane of indigenous signs was an act of assimilation that was shored up by other forms of redefinition of the pre-Hispanic imaginaire. Topography too was conceptually reordered. In the Mexican scenario - and more generally throughout the Americas - the environment was grasped in new ways. Reconstituting places with European-like names was part of the process of classification. The suppression of indigenous territorial signs reclassified the unfamiliar world. Re-identification and re-naming of places left a European stamp on

\footnotetext{
31 See Biggs' compelling argument that the reconception of spatial form from the 15th century onwards brought a new political imagination of territory in "Putting the State on the Map", 374- 405 .

${ }^{32}$ See Hale, The Civilization of Europe, 15-27 and Suarez, Shedding the Veil, ch. 6 and 7.

${ }^{33}$ Pagden, Lords of All the World, $27-9$.

${ }^{34}$ Todorov and Greenblatt are the seminal thinkers in this line of argument. See Todorov, The Conquest of America and Greenblatt, Marvellous Possessions.

${ }^{35}$ Gruzinski, The Conquest of Mexico, 52-5.
} 
the land..$^{36}$ Comparison of known American geographical features with the familiar European landscape acted discursively to tame the land. Many Amerindian words were appropriated. Also Inca and Aztec maps maintained a coexistence with Hispanic American cartography and were absorbed in some instances. However, there are strong reasons for recognizing that the invention of nomenclature for the new environment, as though it were a tabula rasa, was a vital feature of colonial accommodation to the American world.

Writing and rewriting histories of the continent was a related form of fashioning of civilizational identity. Many changes in historiography were represented in the Spanish Atlantic. ${ }^{37}$ In the 16 th century, the historiographic absorption of Aztec and Mayan sources was more sympathetic to Amerindian perspectives than eighteenth century histories of pre-Colombian societies would prove to be. European historiographic conventions set the narrative structures in both cases, to be sure. Earlier accounts believed the sources to be biased and primitive, but they regarded local information as sufficiently authoritative in the context of an unknown past. Far more authority was conferred on graphic and oral indigenous accounts at this time. In the face of seemingly confounding and contradictory Amerindian histories, the initial chroniclers of the pre-Hispanic past sought to order events in ways that were intelligible to Spaniards and Creoles. They utilized biblical references and metaphors in rendering the past into a single linear narrative. In doing so, they devised methods that gave voice to indigenous interlocutors.

By the eighteenth century, however, this frame of interpretation increasingly clashed with evolutionary thinking associated with Cornelius de Pauw, Abbe Raynal, Buffon, Voltaire, and William Robertson. A new species of history writing thoroughly doubted the reliability of earlier eyewitnesses and questioned the capacity of indigenous script and non-literal reports to amass and order information on past events. Historiographic validity came to depend on a method of philosophical criticism. Historical, philological, and scientific treatises were increasingly judged by the standards of internal consistency. Philosopher-travelers became the new narrators. The framework of evolutionary history was the paradigm of judgment that would override more empirical attempts to describe difference. In Europe, it inspired relatively closed systems of thought that derided American culture, where previous Spanish accounts of the Amerindian world drew stereotyping but, nevertheless more flattering analogies with classical Europe.

In the Spanish Indies, this provoked a sharp reaction. A kind of Spanish-American patriotic epistemology built up a critique of the scientific contempt for the American world and the eyewitnesses who gave account of it. The social standing of Creole interpreters was privileged in the defense of American historiography, where it was resolutely maligned in European versions. Americans thought that only they could understand the complex compendium of local sources that were the raw materials of history. In defending their histories, they were also upholding a partisan position in continent-wide dialogues in Europe that countered social-evolutionary philosophy. This was an epistemological battle over the civilizational eminence of the Americas. It marked out two different basic perceptions of the value of the peoples, societies, and ecosystems that inhabited the Western hemisphere. In other words, by the 18th century, two different orientations indicated a more sharply defined conception of civilizational specificity. Europeans sensed

\footnotetext{
36 Axtell, Beyond 1492, 58-63.

37 This is one of Jorge Cañizares-Esguerra's principal arguments in a revision of Atlantic history. See How to Write the History, particularly ch. 2.
} 
alterity, while Creole Americans differentiated themselves from both Spaniards and northern Europeans and from subaltern mestizos. This battle for cultural possession of the past informed the accumulation of civilizational distinction in the present.

A prevailing sense of radical difference became entrenched in the historical imagination, much as it also guided mapping and place naming. Similarly, the comprehension of other peoples crystallized in different versions of the noble savage motif. The image of the noble savage was more potent in France in the 18th century than anywhere else in Europe. At that time, it designated opposites to the civilized European. The primitive savage was one opposite or, rather, an assembly of opposites. However, traces of the noble savage can be found in earlier representations. It did not originate in Rousseau's romantic essays, or Lahontan's dialogues, although these did much to spread it. It began more modestly in meetings on the frontier, letters, diaries, paintings, and woodcuts. It also survived in the interpretations of artifacts, plants and people transported and exhibited in Europe. ${ }^{38}$ A romantic civilizational image was sharply marked out in the comprehension of the difference of the western continent.

The myths of savagery acquired momentum in the particular contents of separate colonial projects. For the Spanish, in general terms, paganism anthropologically defined the conditions of Amerindian peoples as both barbaric and noble. How it did so varied from the early years of Spanish colonialism to its final period. ${ }^{39}$ The tension between the two sides of the one image enlivened 16th century theological and legal debates over their status as subjects, such as the well-known Valladolid Controversy. This was the main theological dilemma of early Spanish colonialism: how to relate to actual peoples whose genesis and character were unexplained. Ethnographic categories of barbarism were deployed in reference to new races, but this was sufficiently elastic to allow the representation of American natives as virtuous. New data on the Americas was interpreted through the prism of classical (particularly Roman) and biblical analogies as contesting views sought to work out where Amerindians fitted into the anthropography of humanity. The names used in theological and historiographic disputes to describe different things in Caribbean and Mesoamerican cultures invoked familiarity, just as the names of places did so more generally back in the Americas.

Moreover, the signifiers allowed recognition of the internal hierarchies of highland Mesoamerican societies. They constituted a recognizable vocabulary that could partly depict social complexity. Eighteenth century works in the evolutionary philosophy of history disparaged such aids to recognition. The Spanish had earlier conceptualized savagery in un-philosophical terms, according to this view. Too much nobility was accorded to the pre-civil conditions of Mesoamerican cultures and their place in the ranking of civilizations could not be accurately reflected. Of course, the level of differentiation was no longer immediately evident to eighteenth century observers, as the long process of integration of Amerindian communities had simplified previous hierarchies. The writings of ascendant evolutionary historiography reflected indigenes as an amorphous mass of commoners lacking the societal complexity of civilized peoples. This censure of the Amerindian world had an impact on later Spanish images of savagery, subjecting them to an assault on suggestions that virtue and civility could inhere in indigenous cultures. Spanish responses were tempered by the need to defend its history

${ }^{38}$ Whitaker, "The Culture of Curiosity", 75-90.

${ }^{39}$ Canizares-Esguerra, How to Write the History, 38-44, 207. 
of colonialism against the Protestant offensive and by the Bourbon project of modernization. Overall, they proved unsuccessful. Along the way, the ambivalence about indigenous civilizations waned.

Seventeenth century English perceptions of savagery rested on different values. ${ }^{40}$ The indigenous proto-federations of North America did not have the signs of industriousness that were at the core of the Protestant temperament and capitalist ideal. English colonists built an empire of fences in the North Americas with this ideal in mind. Agrarian and village traditions melded with different inflections of Protestantism to reorganize the landscape according to the principles of enclosure. The legality and legitimacy of possession came only with delineation of possession and "improvement" of land. The indigenous mode of production, quite deliberate in its land use, was not recognized as civilized at all. Native American hierarchies were identified, but were not respected because of the value accorded private property.

The English shared general colonial values, but views of their relations with the Indian nations could still vary. The contrast is consistent, however, with emerging noble/ ignoble images. Later, the French would sharpen the vision of noble savagery. They combined romantic reconstruction of the simplicity of native society with exuberance for the progress that civilization allegedly brought. In either English or French versions, the indigenes appeared uncultured. Savagery, in French eyes, came from a condition of proximity to Nature. ${ }^{41}$ The lack of polished manners, the competences of conversation and the arts was an indigenous trait that set them outside of the bounds of civility. Unlike the Spanish, French writers thought the indigenes capable of civilized development, but that they simply did not possess its rudiments.

Ideas about America's pre-Columbian peoples were shared and widely communicated. In the romantic impulse of the 18th century, the image of the noble savage started to lose its national specificity. The transfiguration of American identity blended also mestizo, Creole and slave, although pre-Colombian peoples were reserved a special place. This was a new peak in transatlantic civilizational consciousness and the image of the American noble savage - a figure saturated with European ambiguities - acquired its most mythical features.

A deeper awareness of Western Europe's relative position in the world was evident by the eighteenth century. The word "civilization" itself was only barely in use. However, the widespread consciousness that circumscribed its expression had formed out of the civilizational imaginary. The self-consciousness of Europeans caught up in the civilizing process, as Elias describes it, was forged not only in connection with the territorial consolidation of the state, but also in the civilizational intersection with the Americas. The civilizing process developed not only in the social settings of court society, but also out of the transatlantic exchange of images and impressions of America. The barbaric outsiders, who were the necessary opposite of the courtly ethos of self-restraint, were not just Muslims or commoners. They were also indigenous Americans, mestizos and slaves.

The European civilization that was incarnated in this consciousness combined ethnographic curiosity and different modes of representation. Three centuries of uneven colonial engagement with Amerindian civilizations resulted in the uneven absorption of the newfound hemisphere into Europe's cultural dominion. The American colonies were

${ }^{40}$ Patricia Seed, Ceremonies of Possession, ch. 1.

${ }^{41}$ See Dickason, The Myth of Savage, especially 63-70. 
an alternative point of reference in a civilizational consciousness defined by its interpretive paradigms. Colonial America seemed to contain so many cultural opposites, interpretations of which invigorated Europeans' sense of civilizational singularity. This New World was a presence and a horizon that helped to define the civilizational identity of Western Europe in the early modern era long before the word "civilization" acquired a currency of usage and before its entries in modern dictionaries and encyclopaedia.

\section{BIOGRAPHICAL NOTE}

Jeremy Smith currently teaches in the School of Behavioural and Social Sciences and Humanities at the University of Ballarat, Australia. His current interests and research are reflected in this essay.

\section{REFERENCES}

ARMITAGE, DAVID. The Ideological Origins of the British Empire. Cambridge: Cambridge University Press, 2000.

ARNASON, JOHANN P. "Social Theory and the Concept of Civilisation." Thesis Eleven 20 (1988): $87-$ 105.

. "Culture and Imaginary Significations." Thesis Eleven 22 (1989): 25-45.

. Social Theory and Japanese Experience: the Dual Civilization. London: Kegan Paul International, 1998.

AXTELL, JAMES. Beyond 1492: Encounters in Colonial North America. New York: Open University Press, 1992.

BARTLET, ROBERT. The Making of Europe: Conquest, Colonization, and Cultural Change 950-1350 . London: Allen Lane, 1993.

BIGGS, MICHAEL. "Putting the State on the Map: Cartography, Territory and European State Formation." Comparative Studies in Society and History 41, no. 2 (1999): 374-405.

BOTTIGHEIMER, KARL S. "Ireland in the Westward Enterprise." In The Westward Enterprise: English Activities in Ireland, the Atlantic and America 1480-1650, edited by K. R. Andrews, N. P. Canny and P. E. H. Hair, Liverpool: Liverpool University Press, 1978: 41-65.

CANIZARES-ESGUERRA, JORGE. How to Write the History of the New World: Histories, Epistemologies and Identities in the Eighteenth Century Atlantic World. Stanford: Stanford University Press, 2001.

CANNY, NICHOLAS P. The Elizabethan Conquest: A Pattern Established 1565-1576. New York: Barnes \& Noble Books, 1976.

Kingdom and Colony: Ireland in the Atlantic World 1560-1800. Baltimore and London: The John Hopkins University Press, 1988.

CASTORIADIS, CORNELIUS. The Imaginary Institution of Society. Cambridge, UK: Polity Press, 1987.

- "Radical Imagination and the Social Instituting Imaginary." In Rethinking Imagination: Culture and Creativity, edited by Gillian Robinson and John F. Rundell. London: Routledge, 1994: 136-54.

DICKASON, OLIVE P. The Myth of Savage: And the Beginnings of French Colonialism in the Americas. Alberta: University of Alberta Press, 1984.

DURKHEIM, EMILE and MARCEL MAUSS. "In Between Sociology and Anthropology: Note on the Notion of Civilization." Social Research, 38, no. 4 (1971): 808-13.

EISENSTADT, S. N. The Origins and Diversity of Axial Age Civilizations. Albany: SUNY Press, 1986. 
- European Civilization in a Comparative Perspective: A Study in the Relations between Culture and Social Structure. Oslo: Norwegian University Press, 1987a.

, ed. "Introduction." In Patterns of Modernity. New York: New York University Press, 1987b. ELIAS, NORBERT. The History of Manners, translated by Edmund Jephcott. Oxford: Basil Blackwell, 1978.

State Formation and Civilization. Basil Blackwell, Oxford, 1982.

ELLIS, STEVEN. Ireland in the Age of the Tudors 1447-1603: English Expansion and the End of Gaelic Rule. London: Longman, 1998.

FRANKL, VICTOR. "Imperio Particular e Imperio Universal en las Cartas de Relacion de Hernan Corte." In Theories of Empire 1450-1800, edited by David Armitage. Hampshire, UK: Ashgate Publishing Ltd, 1998: 139-62.

GREenBLATT, STEPHEN. Marvellous Possessions: The Wonder of the New World. Oxford: Clarendon Press, 1991.

GRUZINSKI, SERGE. The Conquest of Mexico: the Incorporation of Indian Societies into the Western World, Sixteenth to Eighteenth Centuries. Cambridge: Polity Press, 1993.

HALE, JOHN. The Civilization of Europe in the Renaissance. London: Harpercollins, 1993.

HUFF, TOBY E. On the Roads to Modernity: Conscience, Science and Civilizations: Selected Writings of Benjamin Nelson. Totowa, New Jersey: Rowman and Littlefield, 1981.

HUNTINGTON, SAMUEL. The Clash of Civilizations and the Remaking of the World Order. New York, Simon and Schuster, 1996.

LANG, JAMES. Conquest and Commerce. New York: Academic, 1975.

MCALISTER, LYLE N. Spain and Portugal in the New World: 1492-1700. Minneapolis: University of Minneasota Press, 1984.

MANCKE, ELIZABETH. "Early Modern Expansion and the Politicization of Oceanic Space." Geographical Review. 89, no. 2 (1999): 225-37.

MORGAN, HILARY. "Mid-Atlantic Blues." Irish Review 11 (1991/2): 50-5.

OHLMEYER, JANE E. "Seventeenth Century Ireland and the New British and Atlantic Histories." American Historical Review 104 (1999): 446-2.

PAGDEN, ANTHONY. European Encounters with the New World. New Haven and London: Yale University Press, 1993.

Lords of All the World: Ideologies of Empire in Spain, Britain and France c. 1500-c. 1800. New Haven, Connecticut: Yale University Press, 1995.

QUINN, DAVID B. "Ireland and Sixteenth Century European Expansion." In Historical Studies: Papers

Read Before the Second Irish Conference of Historians, edited by T D Williams. London: Bowes \& Bowes, 1958.

Ireland and America: Their Early Associations 1500-1640. Liverpool: Liverpool University Press, 1991.

RUNDELL, J. and S. MENNELL. Classical Readings in Culture and Civilization. London: Routledge, 1998. SEED, PATRICIA. Ceremonies of Possession in Europe's Conquest of the New World 1492-1640.

Cambridge: Cambridge University Press, 1995.

SMITH, JEREMY. "Theories of State Formation and Civilisation in Johann P Arnason and Shmuel

Eisenstadt's Comparative Sociologies of Japan." Critical Horizons 3, no. 2 (2002): 225-51. SUAREZ, THOMAS. Shedding the Veil: Mapping the European Discovery of America and the World. London: World Scientific Publishing, 1992.

TODOROV, TZVETAN. The Conquest of America: The Question of the Other. New York: Harper \& Row, 1992. 
WHITAKER, KATIE. "The Culture of Curiosity." In Cultures of Natural History, edited by N. Jardine, J. A. Secord and E. C. Spary. Cambridge: Cambridge University Press, 1996: 75-90. 